\section{Yield Stability of Heirloom Dry Bean (Phaseolus vulgaris L.) Cultivars in Midwest Organic Production}

\author{
Hannah R. Swegarden ${ }^{1}$ \\ Department of Horticultural Science, University of Minnesota Twin Cities, \\ Alderman Hall, 1970 Folwell Avenue, St. Paul, MN 55108 \\ Craig C. Sheaffer \\ Department of Agronomy and Plant Genetics, University of Minnesota Twin \\ Cities, Borlaug Hall, 1991 Upper Buford Circle, St. Paul, MN 55108
}

\section{Thomas E. Michaels}

Department of Horticultural Science, University of Minnesota Twin Cities, Alderman Hall, 1970 Folwell Avenue, St. Paul, MN 55108

Additional index words. common bean, landrace, niche markets

\begin{abstract}
Heirloom dry bean (Phaseolus vulgaris L.) cultivars are distinct in their seed characteristics, although little information regarding their performance at the field scale in the Midwest is currently available. Demand for organic heirloom dry beans from direct-toconsumer markets in Minnesota motivated our examination of the crop's suitability for local production. Heirloom cultivars were evaluated on the basis of yield and yield stability at four small-scale organic vegetable productions in southeast Minnesota. Yield data from 2013 and 2014 were subject to static and dynamic stability biplot analyses. The mean yield of heirloom cultivars was $\approx 44 \%$ lower than commercial market class checks included in the trial; heirloom yields ranged from 825 to $2127 \mathrm{~kg} \cdot \mathrm{ha}^{-1}$, with a mean of $1362 \mathrm{~kg} \cdot \mathrm{ha}^{-1}$. Stability analyses and economic incentives suggest that the production of heirloom cultivars, especially 'Jacob's Cattle Gold', 'Lina Sisco's Bird Egg', 'Peregion', and 'Tiger's Eye', could provide growers with the opportunity to diversify their production, differentiate themselves in local markets, and maintain economic return.
\end{abstract}

In response to consumer demand, land dedicated to certified organic dry bean (P. vulgaris L.) production nearly quadrupled in Minnesota between 2008 (241 ha) and 2011 (1011 ha) (Greene et al., 2009; Greene, 2013; USDA, 2011a). A similar trend was observed on a national scale; organic dry bean production increased from $1.08 \%$ to $2.38 \%$ of total dry bean acreage between 2008 and 2011 (USDA, 2011b). Organic dry bean price premiums and ecological system services serve as primary incentives to adopt organic production practices (Kremen and

Received for publication 25 Aug. 2015. Accepted for publication 2 Dec. 2015.

This work was supported by the USDA National Institute of Food and Agriculture Organic Agriculture Research and Extension Initiative (Project No. MIN-13-G24) and represents a portion of the primary author's graduate thesis submitted to the faculty at the University of Minnesota.

We thank the following partners for their field support: Cornercopia Student Organic Farm, Gardens of Eagan, Foxtail Farm, and Fresh Earth Farms and thanks to Joshua Larson, Claire Flavin, Sanna Beek, Trentin Tracanna, and Laura Hayes for their technical support.

Reference to commercial products or trade names is made with the understanding that no discrimination is intended and no endorsement by the University of Minnesota is implied.

${ }^{1}$ Corresponding author. E-mail: hrs84@cornell.edu.
Miles, 2012; Maeder et al., 2002; USDA, 2015). Western and southern regions of Minnesota have seen recent growth of diversified organic vegetable producers catering to urban outlets and direct-to-consumer markets, including restaurants, community supported agriculture, and farmer's markets (Adam, 2006; Schnell, 2007; USDA, 2012). For the past 2 years, the Regional Sustainable Development Partnerships (RSDP, unpublished data, 2014) at the University of Minnesota has conducted surveys regarding supply chains and local production of dry beans in Minnesota.

Surveys from RSDP (unpublished data, 2014) suggest that there is new demand among consumers and restaurants for locally produced, organic dry beans. In particular, there is expressed demand for heirloom cultivars with identifiable traits, such as cooking quality, flavor, and interesting seedcoats. Participating restaurant managers cited an average willingness to pay (WTP) of $\$ 10.52$ per kilogram for heirloom, organic dry beans (RSDP, unpublished data, 2014). According to growers who primarily sell their heirloom dry beans through farmer's markets, consumers exhibit a WTP between $\$ 13.20$ and $\$ 17.60$ per kilogram (John Breslin, personal communication, 30 Jan. 2015; Paula Foreman, personal communication, 10 Oct. 2013).

Heirloom cultivars are landrace plant populations that were informally exchanged and cultivated throughout the United States for many generations (Gepts, 1988; Hendrick, 1931; Silbernagel and Hannan, 1988). Seed savers, farmers, and specialty seed companies, however, more often refer to landrace populations as "heirloom,' "heritage," "folk," or "farmer-bred," all of which emphasize a horticultural or anthropological component (Camacho et al., 2006). Heirloom populations are known for their deep cultural connections, traditional uses, and ecological adaptation to the region in which they were first cultivated (Burgess, 1994; Nazarea, 2005). As a result of exchange, migration, and human selection, heirloom cultivars today are typically characterized as populations of variable plants occasionally lacking in desired agronomic traits (Lioi et al., 2005; Rodiño et al., 2009).

Previous studies conducted in northern Colorado (Walters et al., 2011), Michigan (Heilig and Kelly, 2012), and northwest Washington (Wagner et al., 2006) indicated the yields of heirloom dry beans were substantially lower than commercial market class cultivars. Issues related to harvest maturity and labor costs of trellising climbing plant habits were cited as primary yield constraints within heirloom cultivars (Walters et al., 2011); improved disease resistance and architectural traits among modern cultivars provided competitive yield advantages (Heilig and Kelly, 2012). To date, however, yields of heirloom cultivars, specifically upright and bush-type cultivars, have not been evaluated at the field scale in Minnesota. In addition, the diversity of organic production environments and the potential for variability within heirloom cultivars necessitate an analysis of stability across growing environments. The objective of this study was to evaluate yield and yield stability of several heirloom dry bean cultivars across small-scale organic vegetable production environments in southeast Minnesota. This research will provide guidance to small-scale vegetable growers in the region regarding favorable heirloom cultivar choices when supplying novel dry beans to local markets.

\section{Materials and Methods}

Plant material and seed pretreatments. Untreated seed of 17 heirloom dry bean (P. vulgaris L.) cultivars were sourced from commercial vendors (Osborne Family Farms, 2014; Purcell Mountain Farms, 2014; Seed Savers Exchange, 2014; Vermont Bean Company, 2014) (Table 1; Fig. 1). Heirloom cultivars were assumed to be heterogeneous populations of homozygous plants with low levels of outcrossing. These cultivars were selected because of their novel seed appearance, bush-type plant architecture, and potential as a cultivar for local niche markets. Seed size descriptors, including 100 seed weight (g) average seed length (mm), width $(\mathrm{mm})$, and thickness $(\mathrm{mm})$ were collected from original seed stock in 2012 and yield trial stock from 2013 trials (Table 1). In 


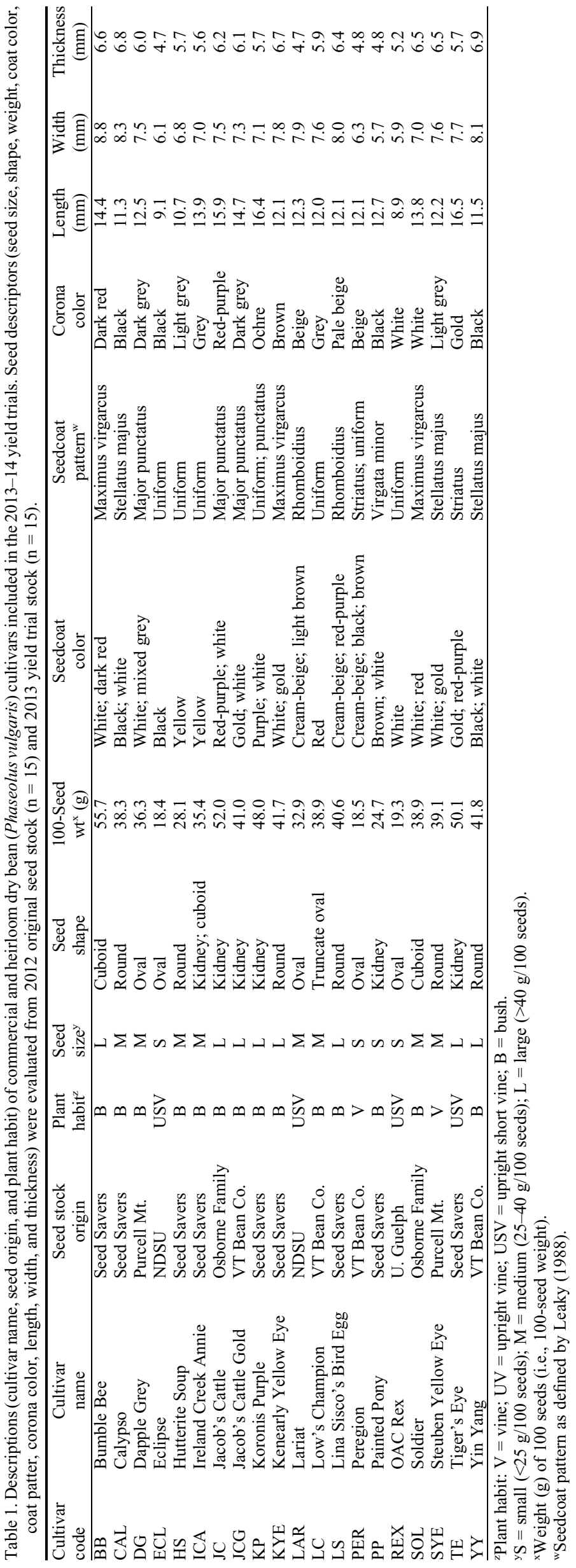

addition, seedcoat characteristics such as coat color, corona color, and seedcoat pattern were recorded (Leaky, 1988). Three commercial market class cultivars, Eclipse, Lariat, and OAC Rex (Michaels et al., 2006; Osorno et al., 2009, 2010) were included as commercial checks in the trial; commercial control cultivars were assumed to be pure lines with low levels of outcrossing. In addition, commercial checks were selected to represent the most widely grown market classes grown in the Midwest and commercial types that show potential in organic production. Germination of all seed stock was tested using the "between paper" method specific to common bean (Rao et al., 2006). Just before planting, seed was inoculated with a commercial source (Novozymes, Franklinton, NC) of nitrogenfixing Rhizobium bacteria (Rhizobium leguminosarum biovar phaseoli) in a peatbased suspension.

Experimental design. Experiments to determine the yield and yield stability of heirloom dry bean cultivars were conducted during 2013 and 2014. Plots were established at four locations: Fresh Earth Farm in Afton, MN; Foxtail Farm in Osceola, WI; Gardens of Eagan in Northfield, MN; and The Cornercopia Student Organic Farm in St. Paul, MN (Table 2). The Northfield, MN, and St. Paul, MN, locations were United States Department of Agriculture certified organic, whereas the Afton, MN, and Osceola, WI, locations had been managed according to the UDSA guidelines for more than 10 years before the onset of the experiment (Paul Burkhouse, personal communication, 2013; Chris James, personal communication, 2013; USDA, 2014). The University of Minnesota's Research Analytical Laboratory (http://ral.cfans.umn.edu/ references/; St. Paul, MN) performed soil fertility tests (Table 3 ) in the fall of 2013 and 2014 using standard extraction methods for $\mathrm{pH}$, organic matter (OM), $\mathrm{P}, \mathrm{K}, \mathrm{Ca}$, and $\mathrm{Mg}$. Previous crops and soil nutrient composition differed among locations (Table 3 ). No fertilizer, insecticides, or herbicides were applied during these experiments. All locations were maintained as nonirrigated, rain-fed sites.

Each experiment was a randomized complete block design with three replications. A block consisted of 20 dry bean cultivars as treatments. Heirloom cultivar Lina Sisco's Bird Egg was omitted from the 2014 trials as a result of improper planting. An experimental plot consisted of a single treatment planted in a 2 -row plot that was $4.6 \mathrm{~m}$ (15 feet) long with $0.61 \mathrm{~m}$ ( 24 inches) row spacing. Seed count was adjusted for germination percentage plus 5\% seedling mortality to obtain a target seeding rate of 215,186 plants/ha $(87,120$ plants/ac $)$ or four plants per $0.304 \mathrm{~m}$ ( 1 foot). The soil had been prepared by chisel plowing and then finished by field cultivating or rototilling before seeding. Experiments were seeded between Julian days 152 and 161 ( 1 June to 10 June) in both seasons. Weedfree plots were maintained using a wheel 

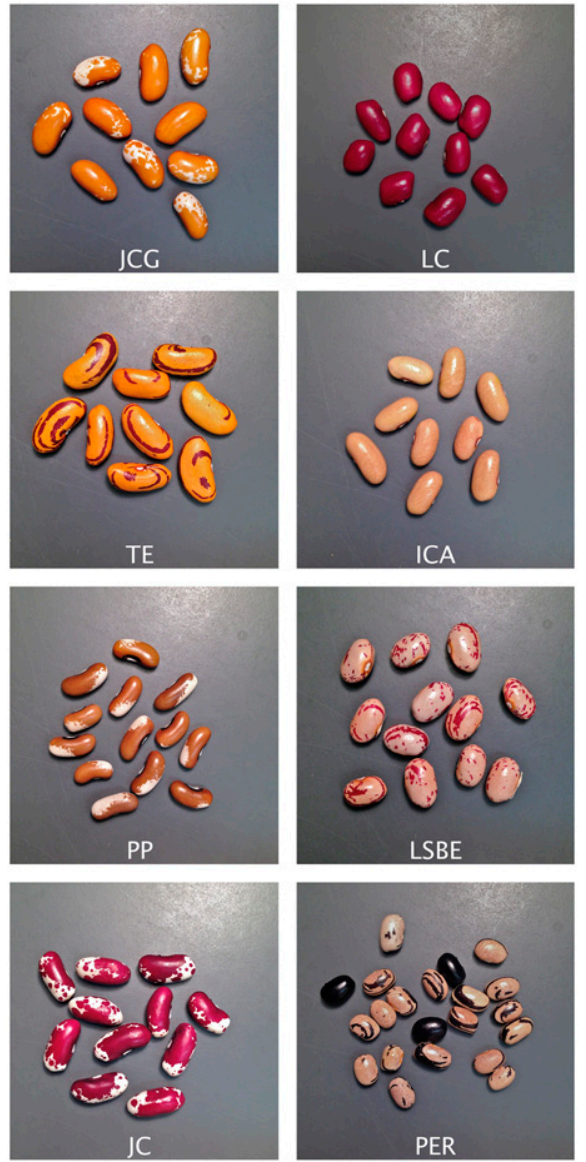
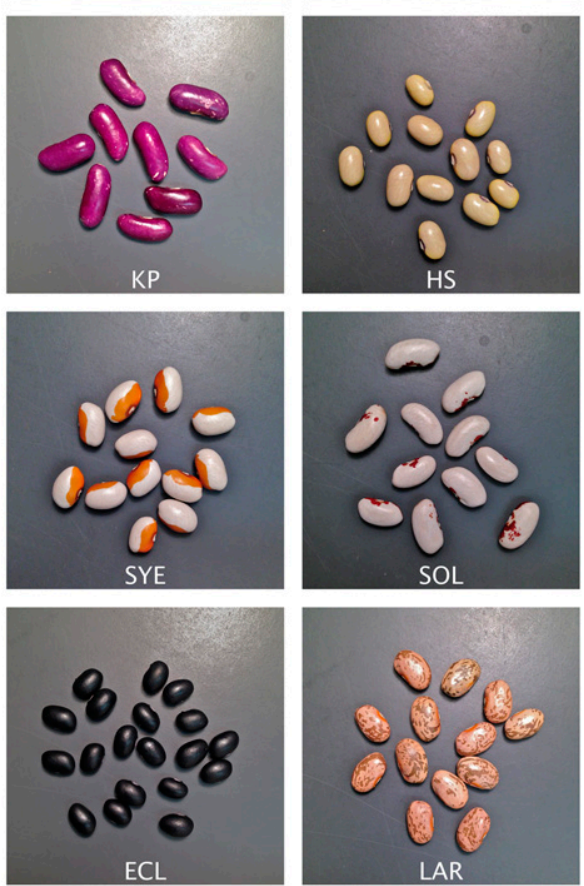
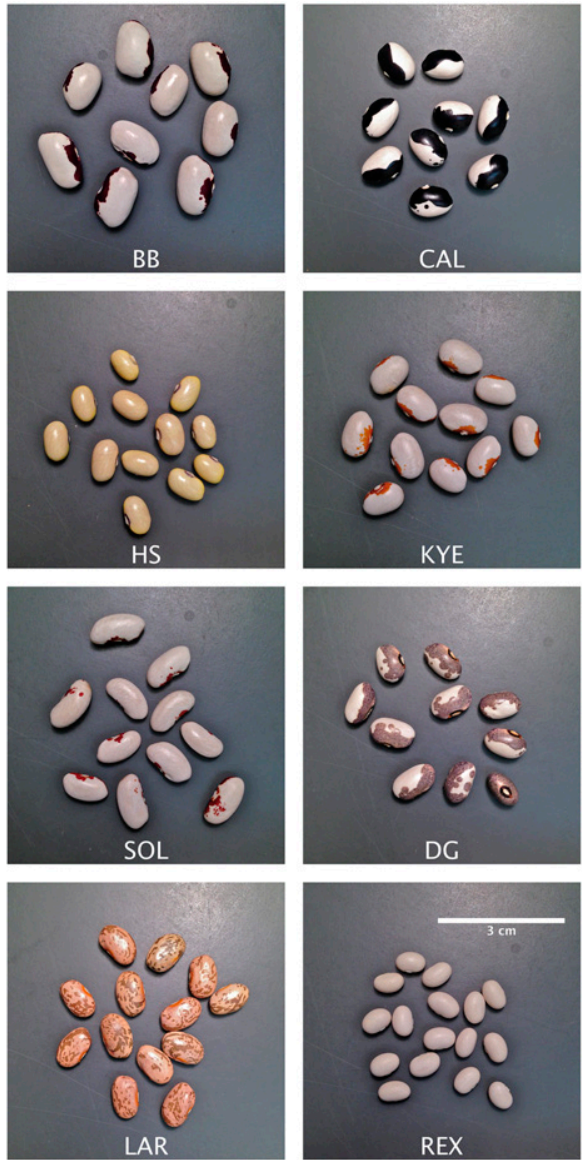

Fig. 1. Photos of twenty dry bean (Phaseolus vulgaris) cultivars included in the 2013-14 yield trials. Heirloom cultivars were selected on the basis of identifiable seedcoats and bush-type plant architecture. Commercial control cultivars are denoted by cultivar codes ECL, LAR, and REX; all others represent heirloom cultivars.

Table 2. Description (location, geographic coordinates, elevation, rainfall, and growing degree days) of trial sites of the 2013-14 dry bean (Phaseolus vulgaris) yield trials. National Weather Service (NOAA Online Weather Data, 2015) estimates represent accumulated rainfall $(\mathrm{mm})$ and growing degree days ('GDD' calculated with base '50') during the Julian period 152-174 (1 June to 1 Oct.).

\begin{tabular}{|c|c|c|c|c|c|c|}
\hline \multirow[b]{2}{*}{ Location } & \multirow[b]{2}{*}{ Coordinates } & \multirow[b]{2}{*}{ Elevation (m) } & \multicolumn{2}{|l|}{2013} & \multicolumn{2}{|l|}{2014} \\
\hline & & & Rainfall (mm) & GDD & Rainfall (mm) & GDD \\
\hline$\overline{\text { Afton, } \mathrm{MN}^{\mathrm{z}}}$ & $44^{\circ} 85^{\prime} \mathrm{N}, 92^{\circ} 82^{\prime} \mathrm{W}$ & 269 & 298 & 2347 & 470 & 2266 \\
\hline Northfield, $\mathrm{MN}^{\mathrm{z}}$ & $44^{\circ} 53^{\prime} \mathrm{N}, 93^{\circ} 18^{\prime} \mathrm{W}$ & 289 & 274 & 2033 & 596 & $-\mathrm{y}$ \\
\hline Osceola, $\mathrm{WI}^{\mathrm{z}}$ & $45^{\circ} 23^{\prime} \mathrm{N}, 92^{\circ} 73^{\prime} \mathrm{W}$ & 315 & 354 & 1467 & 559 & 1967 \\
\hline St. Paul, MN & $44^{\circ} 98^{\prime} \mathrm{N}, 93^{\circ} 19^{\prime} \mathrm{W}$ & 305 & 337 & 2288 & 438 & 2308 \\
\hline
\end{tabular}

${ }^{\mathrm{z} A f t o n}$, Northfield, and Osceola estimates acquired from Hastings, Cannon Falls, and Amery stations, respectively.

y Data missing from August to October.

hoe (Valley Oak, Chico, CA) in the early season and biweekly hand cultivation midto-late season.

Data collection. Plots were hand harvested when all pods were beyond physiological maturity in late September or early October (Nowatzki, 2013). The inner $2.44 \mathrm{~m}$ ( 8 feet) of each 2-row plot was hand harvested. Plant populations within the harvested area were determined during the 2014 growing season. Harvested pods were placed in a low-temperature $\left(35^{\circ} \mathrm{C}\right)$ dryer overnight and then threshed with a small belt thresher (Agriculex, Guelph, Ontario, Canada). To maintain a marketable yield for direct-to-consumer markets, harvested seed was cleaned of debris, splits, and diseased seed before weighing. Reported per-plot yields represent weights at ambient relative humidity expressed in $\mathrm{kg} \cdot \mathrm{ha}^{-1}$.

Statistical analysis. Environments were defined as specific location-year combinations. To account for heterogeneity in variances between heirloom cultivars and commercial checks, yield data were subject to a square root transformation, on the basis of a Box-Cox test (Box and Cox, 1964). All data analyses were performed using R software (version 3.1.2) (R Core Team, 2014); models were executed using the "lme4" package (Bates et al., 2014) and evaluated using the "lmerTest" package (Kuznetsova et al., 2015). To account for the unbalanced nature of the yield data set, the following linear mixed effects model was fit using restricted maximum likelihood:

$$
y_{i j k}=\mu+\alpha_{i}+\beta_{(k) j}+(\alpha \beta)_{i j}+\varepsilon_{i j k}
$$

where $y_{i j k}$ is the measured yield observation of the $i^{i \text { th }}$ cultivar in the $j^{\text {th }}$ environment ( $i=1$, $\left.2, \ldots, \mathrm{g} ; j=1,2, \ldots, e ; k=1,2, \ldots, r_{j}\right), \mu$ is the overall mean, $\alpha_{i}$ is the effect of the $i^{\text {th }}$ cultivar, $\beta_{(k) j}$ is the effect of the $k^{\text {th }}$ replication nested within $j^{\text {th }}$ environment, $(\alpha \beta)_{i j}$ is the effect of the $i^{\text {th }}$ cultivar with the $j^{\text {th }}$ environment, and $\varepsilon_{i j k}$ is the random error term. Fixed effects included $\mu$ and $\alpha_{i}$ whereas $\beta_{(k) j},(\alpha \beta)_{i j}$, and $\varepsilon_{i j k}$ were fit as random effects; random effects, $\beta_{(k) j},(\alpha \beta)_{i j}$, $\varepsilon_{i j k}$ were declared independent, normally distributed, and scaled toward zero with a variance of $\sigma_{\beta}{ }^{2}, \sigma_{\alpha \beta}{ }^{2}, \sigma_{\varepsilon}{ }^{2}$, respectively. The significance of each random effect variance component was determined from the log-likelihood ratio test statistic, comparing models fit via maximum likelihood with and without the variance component in question, with a Chi square distribution and one df (Table 4). Effects were declared significant at $\alpha=0.05$. Profile confidence intervals $(95 \%)$ were calculated for each fixed effect.

Yield stability analyses. Heirloom cultivar stability was evaluated according to the Type I (static) and Type II (dynamic) concepts of stability classified by Lin et al. (1986) and described further by Becker and Léon (1988). Stability under the Type I concept was evaluated by calculating 
Table 3. Soil types, cropping history, and soil nutrient information for trial site locations included in the 2013-14 heirloom dry bean (Phaseolus vulgaris) yield trials. Soil sampling was performed in the fall of 2013 and 2014 across all locations and replications. Soil tests were performed by University of Minnesota's Research Analytical Laboratory.

\begin{tabular}{|c|c|c|c|c|c|c|c|c|c|}
\hline \multicolumn{4}{|c|}{ Site history } & \multicolumn{6}{|c|}{ Fall soil testing results } \\
\hline$\overline{\text { Site }}$ & Soil type & $\mathrm{Yr}$ & Previous crop(s) & $\overline{\mathrm{pH}}$ & OM (\%) & BrayP (ppm) & $\mathrm{NH}_{4} \mathrm{OAc}-\mathrm{K}(\mathrm{ppm})$ & $\mathrm{Ca}(\mathrm{ppm})$ & $\overline{\mathrm{Mg}(\mathrm{ppm})}$ \\
\hline \multirow[t]{2}{*}{ Afton, MN } & Baytown silt loam & 2013 & $\begin{array}{l}\text { Cover mixture of dikon radishes, } \\
\text { annual rye, and crimson clover }\end{array}$ & 5.6 & 4.4 & 9 & 82 & - & - \\
\hline & & 2014 & $\begin{array}{l}\text { Cover mixture of dikon radishes, } \\
\text { annual rye, and crimson clover }\end{array}$ & 5.5 & 4.2 & 11 & 105 & 1406 & 252 \\
\hline \multirow[t]{2}{*}{ Osceola, WI } & Santiago silt loam & 2013 & Onions & 6.9 & 2.4 & 25 & 60 & - & - \\
\hline & & 2014 & Tomatoes & 7.3 & 2.2 & 50 & 77 & 1260 & 266 \\
\hline \multirow[t]{2}{*}{ Northfield, MN } & Wadena loam & 2013 & $\begin{array}{l}\text { Cover mixture of white } \\
\text { clover and annual rye }\end{array}$ & 6.7 & 3.0 & 53 & 136 & - & - \\
\hline & & 2014 & Lettuce followed by soybean/sorghum & 6.5 & 3.9 & 25 & 88 & 2158 & 312 \\
\hline \multirow[t]{2}{*}{ St. Paul, MN } & Waukegan silt loam & 2013 & $\begin{array}{l}\text { Onions, broccoli, peppers, lettuce, } \\
\text { cabbage, tomatoes }\end{array}$ & 6.7 & 3.6 & 143 & 296 & - & - \\
\hline & & 2014 & $\begin{array}{l}\text { Tomatoes, garlic, watermelons, } \\
\text { winter squash eggplant }\end{array}$ & 7.4 & 3.8 & 174 & 444 & 2183 & 383 \\
\hline
\end{tabular}

$\mathrm{OM}=$ organic matter.

Table 4. Random effect variance components and their respective contribution to yield model used to evaluate the 2013-14 heirloom dry bean (Phaseolus vulgaris) yield trials conducted at four locations in southern Minnesota. Models were fit via maximum likelihood with and without the variance component in question and compared using a Chi square $\left(\chi^{2}\right)$ distribution $(\mathrm{df}=1)$.

\begin{tabular}{lccrc}
\hline Effect $^{\mathrm{z}}$ & Variance & SD & Contribution & $\chi^{2 \mathrm{y}}$ \\
\hline$\sigma_{\beta(\mathrm{k})}{ }^{2}$ & 3.248 & 1.802 & $9.2 \%$ & $30.217^{* * *}$ \\
$\sigma_{\beta}{ }^{2}$ & 7.759 & 2.785 & $22.0 \%$ & $87.016^{* * *}$ \\
$\sigma_{\beta \alpha}{ }^{2}$ & 7.58 & 2.75 & $21.5 \%$ & $27.124^{* * *}$ \\
$\sigma_{\varepsilon}{ }^{2}$ & 16.649 & 4.08 & $47.2 \%$ & - \\
\hline
\end{tabular}

${ }^{\mathrm{z}}$ where $\sigma_{\beta(\mathrm{k})}{ }^{2}, \sigma_{\beta}{ }^{2}, \sigma_{\beta \alpha}{ }^{2}$, and $\sigma_{\varepsilon}{ }^{2}$ represent the variance associated with replication nested within environments, environment, cultivar $\times$ environment interaction, and random error, respectively. Note that cultivar effects are fixed.

$\mathrm{y}_{\mathrm{NS}}, *, * *, * * *$ Nonsignificant or significant at $P \leq 0.05$, 0.01 , or 0.001 , respectively.

a cultivar's CV, whereby the square root of the cultivar's variance among environments was divided by the grand mean yield (Francis and Kannenberg, 1978). To visually assess Type I stability, a cultivar's CV was plotted on the $x$-axis against its estimated mean yield $\left(\mathrm{kg} \cdot \mathrm{ha}^{-1}\right)$ on the $y$-axis (Fig. 2). The biplot was divided into four quadrants based on the mean $\mathrm{CV}(23.5 \%)$ and mean observed yield (1525 $\left.\mathrm{kg} \cdot \mathrm{ha}^{-1}\right)$ across cultivars. Stable cultivars within these trials, according to the Type I definition of stability, exhibited high yield, a low $\mathrm{cv}$, and appeared in the upper left quadrant of the biplot.

Visual assessment of Type II (dynamic) stability (Becker and Léon, 1988; Lin et al., 1986) was achieved by plotting an environmental regression coefficient $\left(b_{i}\right)$ (x-axis) against the estimated yield ( $y$-axis) of each heirloom cultivar (Fig. 3). The environmental regression coefficient was calculated from the regression of the predicted random effects of cultivar $\times$ environment $(\alpha \beta)_{i j}$ against the predicted random effect of environment $\beta_{(k) j}$. A negative regression coefficient indicated superior performance in poor (negative $\beta_{(k) j}$ ) environments, a positive coefficient indicated superior performance in favorable (positive $\beta_{(k) j}$ ) environments, and a coefficient of zero indicated stability across all environments. A regression method of stability using an environmental index, presented here as $\beta_{(k) j}$, was first proposed by Eberhart and Russell (1966). This environmental index, however, was not directly compared with the yield in the present modified method. Rather, the cultivar $\times$ environment $(\alpha \beta)_{i j}$ effects were first regressed on the environmental index $\left(\beta_{(k) j}\right)$ as a means of evaluating stability without directly using yield. Much like the Type I stability biplot, the plot was divided into four quadrants by a vertical line drawn at $b_{\mathrm{i}}=0.0$ and a horizontal line drawn at the mean observed yield (1525 kg.ha $\left.{ }^{-1}\right)$. Type II (dynamic) stability in this biplot was best illustrated by cultivars with high yield (i.e., those with a yield greater than the trial mean of $1525 \mathrm{~kg} \cdot \mathrm{ha}^{-1}$ ) and regression coefficient $\left(b_{i}\right)$ near zero.

\section{Results}

The final yield model reported random effect variances of replication nested within environment, environment, and cultivar $\times$ environment interaction that significantly $(P \leq 0.001)$ contributed to the model's variance (Table 4). Effect of environment and cultivar $\times$ environment both accounted for $\approx 22 \%$ of the exhibited variance, where just over $47 \%$ of the model's variance was attributed to random error. No clear correlation between environmental data and yield results was observed, although some of the strongest environmental effects were observed at the Afton and Northfield locations in 2013. Although both locations exhibited very high levels of OM, lower rainfall precipitation in 2013 (Table 2), may have affected pod set and development. Low $\mathrm{pH}$ and $\mathrm{P}$ levels (Table 3) at the Afton location may have also contributed to lower yields, though, given adequate yields in 2014 at the Afton location, these may not be consistent causative factors in yield reduction.

Average yield of commercial control cultivars was $44 \%$ greater than average yield of heirloom cultivars (Table 5). Commercial control cultivar yields ranged from $2355 \mathrm{~kg} \cdot \mathrm{ha}^{-1}$ ('OAC Rex') to $2617 \mathrm{~kg} \cdot \mathrm{ha}^{-1}$ ('Lariat'), with an average yield of $2447 \mathrm{~kg} \cdot \mathrm{ha}^{-1}$. Yields of heirloom cultivars differed $(P \leq 0.05)$ from one another, with yields ranging from $924 \mathrm{~kg} \cdot \mathrm{ha}^{-1}$ ('Dapple Grey') to $2127 \mathrm{~kg} \cdot \mathrm{ha}^{-1}$ ('Peregion') and an average yield of $1362 \mathrm{~kg} \cdot \mathrm{ha}^{-1}$ across all heirloom entries. The yield performance of heirloom cultivar Peregion was $36 \%$ greater than the mean yield of all other heirloom cultivars and $530 \mathrm{~kg} \cdot \mathrm{ha}^{-1}$ greater than the next highest yielding heirloom cultivar, Lina Sisco's Bird Egg. Both commercial checks and heirloom cultivars did not attain target plant populations; commercial checks ( $\overline{\mathrm{x}}=199,853$ plants/ ha) and heirloom ( $\overline{\mathrm{x}}=177,443$ plants/ha) cultivars were $7 \%$ and $18 \%$, respectively, below target plant population levels. Lower plant populations were attributed to earlyseason weed competition, although uniformity of weed densities throughout field plots suggests that differential plant populations did not affect yield comparisons among cultivars.

The average $\mathrm{CV}$ for yield was similar for both commercial $(23.5 \%)$ and heirloom cultivars (23.5\%) (Table 5). 'Jacob's Cattle Gold' had the lowest CV (15.4\%) and third highest yield of the heirloom cultivars $\left(1543 \mathrm{~kg} \cdot \mathrm{ha}^{-1}\right)$. In contrast, 'Dapple Grey' exhibited the highest CV $(36.6 \%)$ and lowest yield $\left(924 \mathrm{~kg} \cdot \mathrm{ha}^{-1}\right)$ of all heirloom cultivars. Five cultivars, Lariat, OAC Rex, Peregion, Jacob's Cattle Gold, and Lina Sisco's Bird Egg displayed Type I (static) stability, though only Jacob's Cattle Gold and Peregion had a CV less than $20 \%$ within that group (Fig. 2). An additional seven heirloom cultivars had cvs less than the average $\mathrm{CV}$ $(23.5 \%)$ across cultivars, though all seven were below the mean yield $\left(1525 \mathrm{~kg} \cdot \mathrm{ha}^{-1}\right)$ of all cultivars in the trial.

Calculated environmental regression coefficients ranged from $b_{i}=-0.568$ ('Lariat') to $b_{i}=0.512$ ('Yin Yang') (Table 5). Visual assessment of the Type II (dynamic) stability biplot identified three heirloom cultivars with an environmental regression coefficient near zero: 'Jacob's Cattle Gold', 'Tiger's Eye', and 'Jacob's Cattle' (Fig. 3). Of those three, only 'Jacob's Cattle Gold' was above the mean yield of all cultivars in the trial (Fig. 3). Three cultivars (Eclipse, Peregion, and Lina 


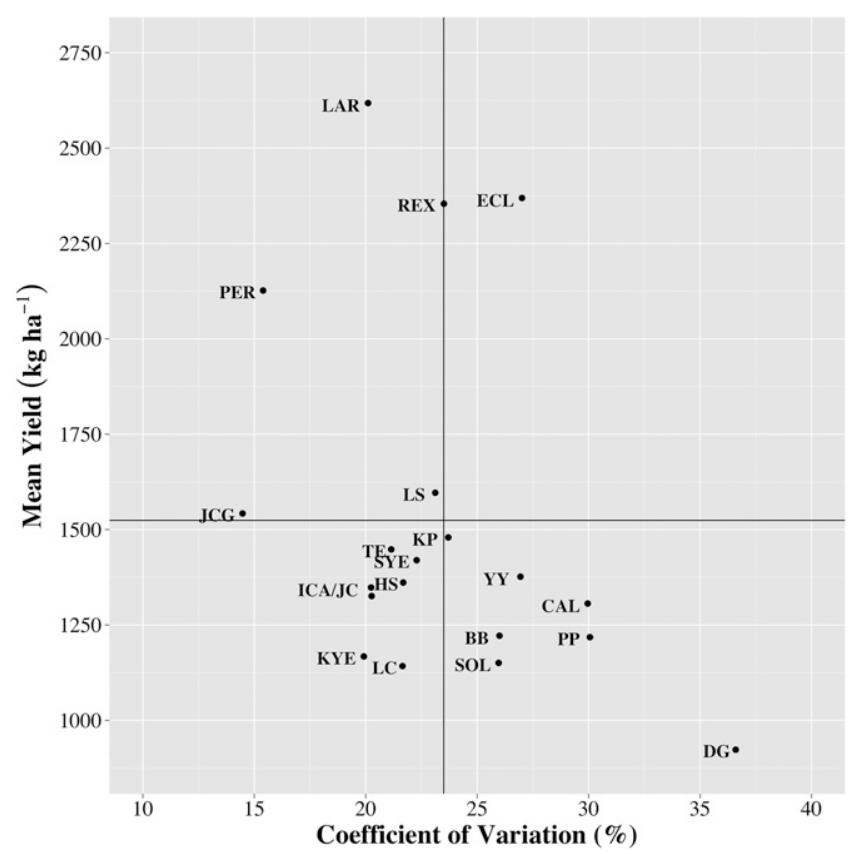

Fig. 2. Type I (static) yield stability of dry bean (Phaseolus vulgaris) cultivars in the 2013-14 dry bean yield trials conducted at four locations in Minnesota. Static stability is best represented by cultivars in the upper left-hand quadrant (i.e., those with high yield and a low cv). Commercial control cultivars are denoted by cultivar codes ECL, LAR, and REX; all others represent heirloom cultivars. Stability parameters for heirloom cultivar LS represent estimates from only the 2013 growing season.

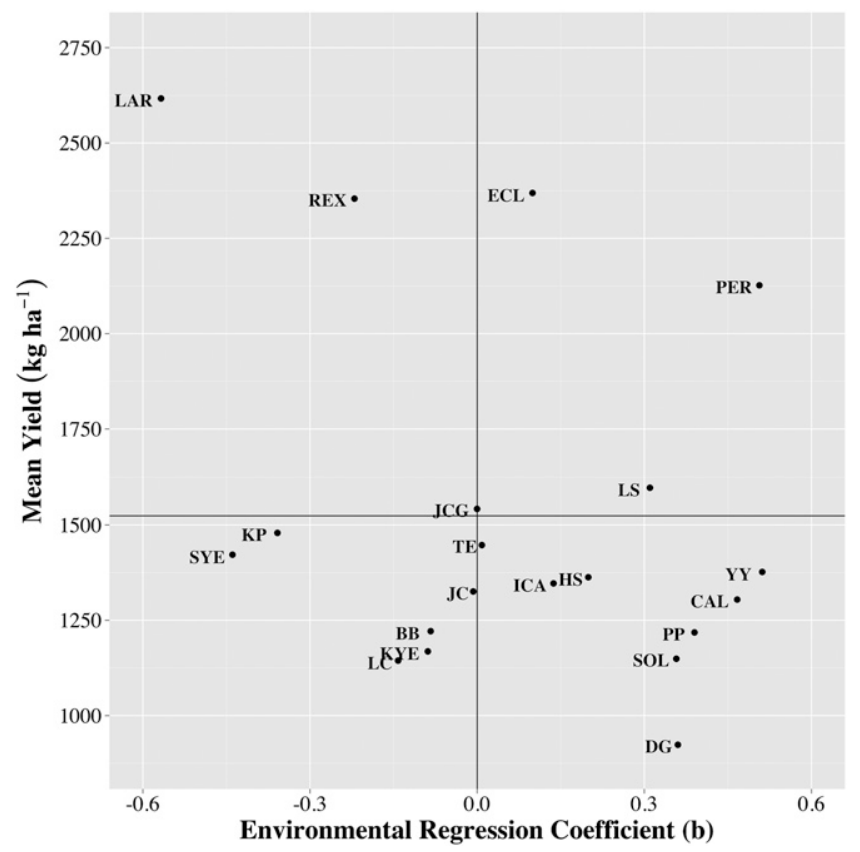

Fig. 3. Type II (dynamic) yield stability of dry bean (Phaseolus vulgaris) cultivars in the 2013-14 dry bean yield trials conducted at four locations in Minnesota. Dynamic stability is best represented by cultivars with high yield (i.e., $>1525 \mathrm{~kg} \cdot \mathrm{ha}^{-1}$ ) and an environmental regression coefficient $\left(b_{i}\right)$ near zero. Commercial control cultivars are denoted by cultivar codes ECL, LAR, and REX; all others represent heirloom cultivars. Stability parameters for heirloom cultivar LS represent estimates from only the 2013 growing season.

Sisco's Bird Egg) were placed in the upper right-hand quadrant of the plot, indicating superior yield in favorable environments (Fig. 3). Two commercial cultivars, Lariat and OAC Rex appeared in the upper left-hand quadrant, suggesting a competitive yield advantage in unfavorable environments; 'Eclipse' exhibited the smallest environmental regression coefficient $\left(b_{i}=0.099\right)$ of all commercial cultivars. Though heirloom cultivars Steuben Yellow Eye and Koronis Purple yielded below the trial mean, their negative environmental regression coefficients suggest a yield advantage in unfavorable environments. In no instance, however, was a cultivar's mean yield performance in unfavorable environments superior to its mean yield performance in favorable environments (Fig. 3).

\section{Discussion}

The assessment of heirloom cultivar yield performance in Minnesota was accented by yield stability evaluation. Examination of the $95 \%$ profile confidence intervals indicated a significant difference between the highest and lowest yielding heirloom cultivars, Peregion and Dapple Grey, but there were 11 cultivars with intermediary $\left(1200-1500 \mathrm{~kg} \cdot \mathrm{ha}^{-1}\right)$ yield performance that were not readily distinct in their performance (Table 5). Without additional stability analyses, cultivars Koronis Purple, Steuben Yellow Eye, and Ying Yang would have been selected as superior on the basis of yield alone. These cultivars, however, did not appear readily stable according to either the Type I or Type II stability assessments.

Under the Type I (static) stability concept, a cultivar is considered stable if its amongenvironment variance is relatively small and its performance is unaffected by changing environmental conditions (Becker and Léon, 1988; Lin et al., 1986). In that sense, this stability parameter is the best estimate of a cultivar's biological stability, independent of other cultivar treatments in the trial. Lin et al. (1986) indicated that a satisfactory Type I stability parameter (i.e., CV) is often associated with poor yield performance, which makes the results of the heirloom yield trials somewhat counterintuitive. Half of the heirloom cultivars in this trial exhibited low variation and (relatively) high yield (Fig. 2). This trend may be unique to heirloom dry bean cultivars, whereby greater plant-toplant variation may exist within the cultivar and, as a result, lower variation across environments. Further breeding work is required to estimate variation within these populations, but, given that the mean $\mathrm{CV}$ of all heirloom cultivars was the same as the commercial control cultivars, it can be assumed that heirloom cultivars exhibit adequate static stability.

The Type II (dynamic) stability biplot (Fig. 3) is a unique way to use the predicted environmental effects in a linear mixed effects model as a means of simultaneously selecting a cultivar for high yield and stability across environments. This biplot depicts dynamic stability that incorporates the predicted effect of cultivar $\times$ environment regressed on an environmental index, which, in this case, was the predicted effect of each environment (Eberhart and Russell, 1966; Lin et al., 1986). The Type II (dynamic) stability biplot is convenient for identifying cultivars whose yields respond predictably to increased agronomic inputs and/or management practices (Ferreira et al., 2006). In addition, this biplot allows for visualization of cultivars that may retain some selective yield advantage to abiotic stressors or are better adapted to poor environmental 
Table 5. Ranked yield results (cultivar name, yield, 95\% confidence interval, cV across locations, and environmental regression coefficient) from the 2013-14 dry bean (Phaseolus vulgaris) yield trials conducted at four locations in southern Minnesota. Trait averages for commercial control cultivars have been tabulated separately from heirloom cultivars.

\begin{tabular}{|c|c|c|c|c|c|c|}
\hline & \multirow[b]{2}{*}{ Cultivarname } & \multirow[b]{2}{*}{ Yield $\left(\mathrm{kg} \cdot \mathrm{ha}^{-1}\right)$} & \multicolumn{2}{|c|}{ 95\% Profile CI } & \multicolumn{2}{|c|}{ Stability analyses } \\
\hline & & & Lower & $\overline{\text { Upper }}$ & $\mathrm{CV}(\%)$ & $b_{i}$ \\
\hline \multirow[t]{4}{*}{ Control cultivars } & Lariat & 2617 & 2307 & 2946 & 20.1 & -0.568 \\
\hline & Eclipse & 2368 & 2074 & 2682 & 27.0 & 0.099 \\
\hline & OAC Rex & 2355 & 2062 & 2668 & 23.5 & -0.22 \\
\hline & Mean & 2447 & 2148 & 2765 & 23.5 & - \\
\hline \multirow[t]{18}{*}{ Heirloom cultivars } & Peregion & 2127 & 1848 & 2424 & 15.4 & -0.507 \\
\hline & Lina Sisco's Bird Egg ${ }^{z}$ & 1597 & 1300 & 1927 & 23.1 & 0.31 \\
\hline & Jacob's Cattle Gold & 1543 & 1307 & 1797 & 14.5 & -0.001 \\
\hline & Koronis Purple & 1479 & 1249 & 1729 & 23.7 & -0.359 \\
\hline & Tiger's Eye & 1448 & 1220 & 1696 & 21.1 & 0.008 \\
\hline & Steuben Yellow Eye & 1421 & 1195 & 1666 & 22.3 & -0.44 \\
\hline & Yin Yang & 1376 & 1154 & 1617 & 26.9 & 0.512 \\
\hline & Hutterite Soup & 1362 & 1140 & 1604 & 21.7 & 0.199 \\
\hline & Ireland Creek Annie & 1347 & 1128 & 1586 & 20.2 & 0.137 \\
\hline & Jacob's Cattle & 1326 & 1108 & 1563 & 20.3 & -0.006 \\
\hline & Calypso & 1305 & 1088 & 1543 & 30.0 & 0.466 \\
\hline & Bumble Bee & 1221 & 1013 & 1449 & 26.0 & -0.084 \\
\hline & Painted Pony & 1218 & 1008 & 1450 & 30.0 & 0.391 \\
\hline & Kenearly Yellow Eye & 1168 & 958 & 1399 & 19.9 & -0.089 \\
\hline & Soldier & 1150 & 948 & 1372 & 26.0 & 0.358 \\
\hline & Low's Champion & 1143 & 941 & 1364 & 21.7 & -0.142 \\
\hline & Dapple Grey & 924 & 744 & 1124 & 36.6 & 0.361 \\
\hline & Mean & 1362 & 1138 & 1606 & 23.5 & - \\
\hline
\end{tabular}

${ }^{\mathrm{z}}$ Data collected only during 2013 growing season.

conditions (i.e., those that appear in the upperleft quadrant).

Kelly et al. (1987) noted that factors relating to plant habit, growth rate, and center of domestication notably affect the yield stability among dry bean cultivars. In general, Andean (large-seeded) cultivars exhibit lower yield and stability than their Mesoamerican (small and medium-seeded) counterparts. As such, the yield and yield stability comparisons between commercial control cultivars, all three of which were of Mesoamerican origin, and Andean heirloom cultivars were slightly predisposed to favoring commercial control cultivars. Regardless, the yield of larger-seeded heirloom cultivars Jacob's Cattle Gold and Tiger's Eye were relatively stable from both biological and agronomic perspectives (Becker and Léon, 1988; Lin et al., 1986). The relatively high yield of 'Lina Sisco's Bird Egg' and 'Peregion' also make them interesting cultivars to explore further.

Production of heirloom cultivars, however, is not without specific production and quality limitations. The large percentage of variation attributed to error in this study was most likely because of seed processing after harvest, in which all diseased and split seed was removed to represent a yield for direct-to-consumer markets. Diseases, particularly common bacterial blight and bean common mosaic virus, were noted throughout both years of trialing. Issues regarding consistent, clean seed supply will need to be addressed if small-scale producers intend to purchase seed on a yearly basis, as most specialty seed companies offer heirloom seed in one pound increments and typically have a limited supply. Researchers at the Organic Seed Alliance, University of Vermont, and Washington markets within the Twin Cities and Greater Minnesota regions.

\section{Literature Cited}

Adam, K.L. 2006. Community supported agriculture. ATTRA - National Sustainable Agriculture Information Service. 5 Mar. 2015.<https:// attra.ncat.org/attar-pub/summaries/summary. php?pub=262>

Bates, D., M. Maechler, B. Bolker, and S. Walker. 2014. Ime4: Linear mixed-effects models using Eigen and S4_. R package version 1.1-7. 15 Oct. 2014. $<$ http://CRAN.R-project.org/package=lme4>.

Becker, H.C. and J. Léon. 1988. Stability analysis in plant breeding. Plant Breed. 101:1-23.

Box, G.E.P. and D.R. Cox. 1964. An analysis of transformations. J. R. Stat. Soc., B 26:211-252.

Burgess, M.A. 1994. Cultural responsibility in the preservation of local economic plant resources. Biodivers. Conserv. 3:126-136.

Camacho Villa, T.C., N. Maxted, M. Scholten, and B. Ford-Lloyd. 2006. Defining and identifying crop landraces. Plant Genet. Resources. 3(3):373-384

Colley, M., J. Navazio, and L. DiPietro. 2010. A seed saving guide for gardeners and farmers. Organic Seed Alliance, Publications. 7 Mar. 2015. <http:// www.seedalliance.org/publications $>$.

Eberhart, S.A. and W.A. Russell. 1966. Stability parameters for comparing varieties. Crop Sci. 6:36-40.

State University, have all begun to experiment with small-scale threshing and seed cleaning equipment suited to small-scale production (Colley et al., 2010; Harwood, 2011; Miles, 2015). In all likelihood, these cultivars will be produced on very small acreage (i.e., $<1$ acre), but concerted efforts will still need to be made to produce enough quality seed to fulfill market demand.

Heirloom cultivars, in particular Jacob's Cattle Gold, Lina Sisco's Bird Egg, Peregion, and Tiger's Eye, are suitable for local organic production according to the yield and yield stability analyses performed herein. Our results are some of the first to highlight field-scale yield estimates for heirloom dry beans produced in the Midwest. Differences between the yield performance of commercial control cultivars and heirloom cultivars may seem drastic, but, when the economic incentives are considered, heirloom cultivars become a viable marketing option. Recent Minnesota surveys indicated that the organic dry beans could obtain $\$ 6.27 \cdot \mathrm{kg}^{-1}$ for nonheirloom and $\$ 10.52 \cdot \mathrm{kg}^{-1}$ of heirloom cultivars in directto-consumer markets (RSDP, unpublished data, 2014). Given that the mean yield of commercial checks $\left(2,447 \mathrm{~kg} \cdot \mathrm{ha}^{-1}\right)$ was $44 \%$ greater than the mean yield of heirloom cultivars $\left(1,362 \mathrm{~kg} \cdot \mathrm{ha}^{-1}\right)$, the price differential accounts for all but $6 \%$ of the discrepancy in estimated gross profit per hectare between commercial $\left(\$ 15,342 \cdot \mathrm{ha}^{-1}\right)$ and heirloom $\left(\$ 14,348 \cdot \mathrm{ha}^{-1}\right)$ cultivars grown in organic settings. Further, small-scale producers that sell their organic beans to farmer's markets stand to make an even greater profit. These results lead to the conclusion that heirloom dry beans offer small-scale organic producers economic incentives and a niche in direct-to-consumer
Ferreira, D.F., C.G. Demétrio, B.F.J. Manly, A.A. Machado, and R. Vencovsky. 2006. Statistical models in agriculture: Biometrical methods for evaluating phenotypic stability in plant breeding. Cerne 12(4):373-388.

Francis, T.R. and L.W. Kannenberg. 1978. Yield stability studies in short-season maize. I. A descriptive method for grouping genotypes. Can. J. Plant Sci. 58:1029-1034.

Gepts, P. 1988. Phaseolin as an evolutionary marker, p. 215-241. In: P. Gepts (ed.). Genetic resources of Phaseolus beans. Kluwer Academic Publishers, Dordrecht, Holland.

Greene, C. 2013. Growth patterns in the U.S. organic industry. In: Amber Waves Magazine, United States Department of Agriculture, Economic Research Service (ERS). 14 Nov. 2014. $<$ http://www.ers.usda.gov/amber-waves/2013october/growth-patterns-in-the-us-organicindustry.aspx\#.VGZrQfTF9D>.

Greene, C., C. Dimitri, B.H. Lin, W. McBride, L. Oberholtzer, and T.A. Smith. 2009. Emerging issues in the U.S. organic industry. U.S. Department of Agriculture, Economic Research Service (ERS). EIB-55. 5 Mar. 2015. <http://www. ers.usda.gov/media/155923/eib55_1_.pdf>.

Harwood, H. 2011. Grain processing equipment: From field to bin. University of Vermont Extension Bulletin. 11 Mar. 2015. <http:// umaine.edu/localwheat/files/2012/06/GrainProcessing-Equipment.pdf $>$.

Heilig, J.A. and J.D. Kelly. 2012. Performance of dry bean genotypes grown under organic and conventional production systems in Michigan. Agron. J. 104:1485-1492.

Hendrick, U.P. 1931. The vegetables of New York: The beans of New York. New York Geneva Agr. Expt Sta. Rpt. 1(2):1-110.

Kelly, J.D., M.W. Adams, and G.V. Varner. 1987. Yield stability of determinate and indeterminate dry bean cultivars. Theor. Appl. Genet. 74:516-521.

Kremen, C. and A. Miles. 2012. Ecosystem services in biologically diversified versus conventional farming systems: Benefits, externalities, and trade-offs. Ecol. Soc. 17(4):40. 
Kuznetsova, A., P.B. Brockhoff, and R.H. Bojesen Christensen. 2015. lmerTest: Tests in linear mixed effects models. $\mathrm{R}$ package version 2.0-20. 4 Feb. 2015. <http://CRAN.R-project.org/ package $=$ lmerTest $>$.

Leaky, C.L.A. 1988. Genotypic and phenotypic markers in common bean, p. 245-327. In: P. Gepts (ed.). Genetic resources of Phaseolus beans. Kluwer Academic Publishers, Dordrecht, Holland.

Lin, C.S., M.R. Binns, and L.P. Lefkovitch. 1986. Stability analysis: Where do we stand? Crop Sci. 26:894-900.

Lioi, L., A.R. Piergiovanni, D. Pignone, S. Puglisi, M. Santantonio, and G. Sonnante. 2005. Genetic diversity of some surviving on-farm Italian common bean (Phaseolus vulgaris L.) landraces. Plant Breed. 124:576-581.

Maeder, P., A. Fliessbach, D. Dubois, L. Gunst, P. Fried, and U. Niggli. 2002. Soil fertility and biodiversity in organic farming. Science 296:1694-1697.

Michaels, T.E., T.H. Smith, J. Larsen, A.D. Beattie, and K.P. Pauls. 2006. OAC Rex common bean. Can. J. Plant Sci. 86:733-736.

Miles, C. 2015. Small-scale dry bean harvesting. Mount Vernon NWREC, Vegetable Research and Extension. 5 Mar. 2015. <http://vegetables. wsu.edu/NicheMarket/SmallScaleHarvesting. $\mathrm{html}>$.

Nazarea, V.D. 2005. Heirloom seeds and their keepers. 1st ed. The University of Arizona Press, Tuscon, AZ.

NOAA Online Weather Data. 2015. National Weather Service. 9 Jan. 2015. <http://www. weather.gov/climate/>.

Nowatzki, J. 2013. Harvesting dry bean, p. 106. In: H. Kandel (ed.). Dry bean production guide. NDSU Ext. Bul. A1133. 15 Dec. 2014. <http:// www.ag.ndsu.edu/publications/landing-pages/ crops/dry-bean-production-guide-a-1133>.

Osborne Family Farm. 2014. Heirloom beans. Osborne Family Farm, Charleston, ME. 19 Dec. 2014. < http://www.osbornefamilyfarm. com/Products.html $>$.
Osorno, J.M., K.F. Grafton, J.B. Rasmussen, G.A. Rojas-Cifuentes, R. Gelin, and A.J. Vander-Wal. 2009. Release of 'Eclipse' black bean. Annual Rpt. Rpts. of Bean Improvement Coop. and Natl. Dry Bean Council Res. Conf. p. 160-161. 19 Dec. 2014. <http:// naldc.nal.usda.gov/nalde/download.xhtml? id $=$ IND44207421\& content $=$ PDF $>$.

Osorno, J.M., K.F. Grafton, G.A. Rojas-Cifuentes, R. Gelin, and A.J. Vander Wal. 2010. Registration of 'Lariat' and 'Stampede' pinto beans. J. Plant Registrations. 4:5-11, doi: 10.3198/ jpr2009.03.0143crc.

Purcell Mountain Farms. 2014. Dried beans. Purcell Mountain Farms, Moyie Springs, ID. 19 Dec. 2014. <http://www.purcellmountainfarms.com/ Dried\%20Beans.htm>.

R Core Team. 2014. R: A language and environment for statistical computing. R Foundation for Statistical Computing, Vienna, Austria. $<\mathrm{http}$ ://www.R-project.org/>.

Rao, N.K., J. Hanson, M.E. Dulloo, K. Ghosh, D. Nowell, and M. Larinde. 2006. Manual of seed handling in genebanks. Handbooks for Genebanks No. 8. Biodiversity International, Rome, Italy.

Rodiño, A.P., A.B. Monteagudo, A.M. De Ron, and M. Santalla. 2009. Ancestral landraces of common bean from the south of Europe and their agronomic value for breeding programs. Crop Sci. 49:2087-2099.

Schnell, S.M. 2007. Food with a farmer's face: Community-supported agriculture in the United States. Geogr. Rev. 97(4):550-564.

Seed Savers Exchange. 2014. Online store: Beans. Seed Savers Exchange, Decorah, IA. 19 Dec. 2014. <http://www.seedsavers.org/onlinestore/ bean/>.

Silbernagel, M.J. and R.M. Hannan. 1988. Utilization of genetic resources in the development of commercial bean cultivars in the U.S.A., p. 561-596. In: P. Gepts (ed.). Genetic resources of Phaseolus beans. Kluwer Academic Publishers, Dordrecht, Holland.
U.S. Department of Agriculture (USDA). 2011a. Table 07 - U.S. certified organic beans, by State, 2011. Economic Research Service (ERS), Washington, DC. Nov. 2013.

U.S. Department of Agriculture (USDA). 2011b. Table 03 - Certified organic and total U.S. acreage, selected crops and livestock, 1995-2011. Economic Research Service (ERS), Washington, DC. Nov. 2013. <http://usda.mannlib.cornell. edu/MannUsda/viewDocumentInfo.do? documentID $=1394>$.

U.S. Department of Agriculture (USDA). 2012. Table 43. Selected practices: 2007. 2012 Census of Agriculture. National Agriculture Statistics Service (NASS), Washington, DC. 5 Mar. 2015. <http://www.nal.usda.gov/afsic/pubs/csa/ csa.shtml $>$.

U.S. Department of Agriculture (USDA). 2014. Agricultural Research Service (ARS), National Organic Program, National Organic Program Regulations (Standards), Washington, DC. 11 Feb. 2014. <http://apps.fas.usda. gov/gats/default.aspx $>$.

U.S. Department of Agriculture (USDA). 2015. Bean market news, Vol. 5, No. 09, Tue 3 Mar 2015. Agricultural Marketing Service (AMS), Washington, DC. 5 Mar. 2015. <http://usda. mannlib.cornell.edu/usda/ams/LSWBEAN. pdf>.

Vermont Bean Seed Company. 2014. Beans. Vermont Bean Seed Company, Randolph, WI. 19 Dec. 2014. <http://www.vermontbean.com/dc. asp? $=11>$.

Wagner, J., C. Miles, and P.N. Miklas. 2006. Evaluating heirloom dry bean varieties as a niche market crop in the maritime northwest. Annu. Rep. Bean Improv. Coop. 49:129-130.

Walters, H., M.A. Brick, and J.B. Ogg. 2011. Evaluation of heirloom bean production in Northern Colorado. In: H.F. Schwartz (ed.). Colorado Bean News Bul. 24(1):10. 5 Mar. 2015. <http://www. coloradodrybeans.com/yahoo_site_admin/assets/ docs/CBN_241.139101918.pdf?. 